\title{
Digital soil assessment of salinization and sodification in agricultural areas
}

\author{
Christian Omuto ${ }^{1}$, Mobarak Magid ${ }^{2}$, Mapeshone Bottle ${ }^{3}$, Koetlisi Koetlisi ${ }^{4}$, Ahmadzai \\ Hameedullah $^{5}$, and Nuha Mohammed ${ }^{2}$ \\ ${ }^{1}$ University of Nairobi \\ ${ }^{2}$ Agriculture Research Centre \\ ${ }^{3}$ National University of Lesotho \\ ${ }^{4}$ Ministry of Forestry and soil conservation \\ ${ }^{5}$ Ministry of Agriculture, Irrigation and Livestock
}

November 10, 2020

\begin{abstract}
Soil salinization and sodification are types of degradation due to salt accumulation in the soil. They develop in all climatic zones but are prevalent in arid and semi-arid areas. Assessment of their true occurrence is challenging owing to inadequate consideration of their evolution, lack of harmonization steps, and omission of diagnostic soil properties in the assessment. This paper developed a new assessment protocol using combined application of time-series diagnostic soil indicators, remote sensing, and environmental variables related to the occurrence of soil salts. The protocol focuses on standardization of the soil indicators, digital soil mapping, and application of classification schemes to identify levels of salt accumulation in the soil. It was tested in Lesotho, Afghanistan, and Sudan using measured soil electrical conductivity, pH, and exchangeable sodium percent, and covariates such as relief, remote sensing indicators of soil salinity, climate, hydrogeology, and land cover between 2001 and 2018. It was able to identify different types of salt-affected soils and levels of salt accumulation with over $80 \%$ accuracy on holdout samples. It identified emerging subsoil $(30-100 \mathrm{~cm})$ salt problems in agricultural areas in Lesotho, advancing topsoil $(0-30 \mathrm{~cm})$ salinization and subsoil sodification in agricultural areas in Sudan, and salinization of saline topsoils in Afghanistan. It also established important environmental covariates which can be used in periodic monitoring of salt accumulation in the soil. We recommend its wide application in different temporal and spatial scales to improve its performance in identifying salt accumulation in agricultural areas
\end{abstract}

\section{Hosted file}

Manuscript_salt-affected soils_Omuto.pdf available at https://authorea.com/users/ 374577/articles/492076-digital-soil-assessment-of-salinization-and-sodification-inagricultural-areas

\section{Hosted file}

Table 1 Summary of measured soil properties.pdf available at https://authorea.com/users/ 374577/articles/492076-digital-soil-assessment-of-salinization-and-sodification-inagricultural-areas

\section{Hosted file}

Table 2 Remote sensing indices of salt problems in soil.pdf available at https:// authorea.com/users/374577/articles/492076-digital-soil-assessment-of-salinization-andsodification-in-agricultural-areas 


\section{Hosted file}

Table 3 Classification of salt problems in soil.pdf available at https://authorea.com/users/ 374577/articles/492076-digital-soil-assessment-of-salinization-and-sodification-inagricultural-areas

\section{Hosted file}

Table 4 Degree of salt acummulation.pdf available at https://authorea.com/users/ 374577/articles/492076-digital-soil-assessment-of-salinization-and-sodification-inagricultural-areas

\section{Hosted file}

Table 5 Summary of spatial modelling of indicators of salt accumulations.pdf available at https://authorea.com/users/374577/articles/492076-digital-soil-assessment-ofsalinization-and-sodification-in-agricultural-areas

\section{Hosted file}

Table 6 Salt accumulation in agricultural areas.pdf available at https://authorea.com/users/ 374577/articles/492076-digital-soil-assessment-of-salinization-and-sodification-inagricultural-areas
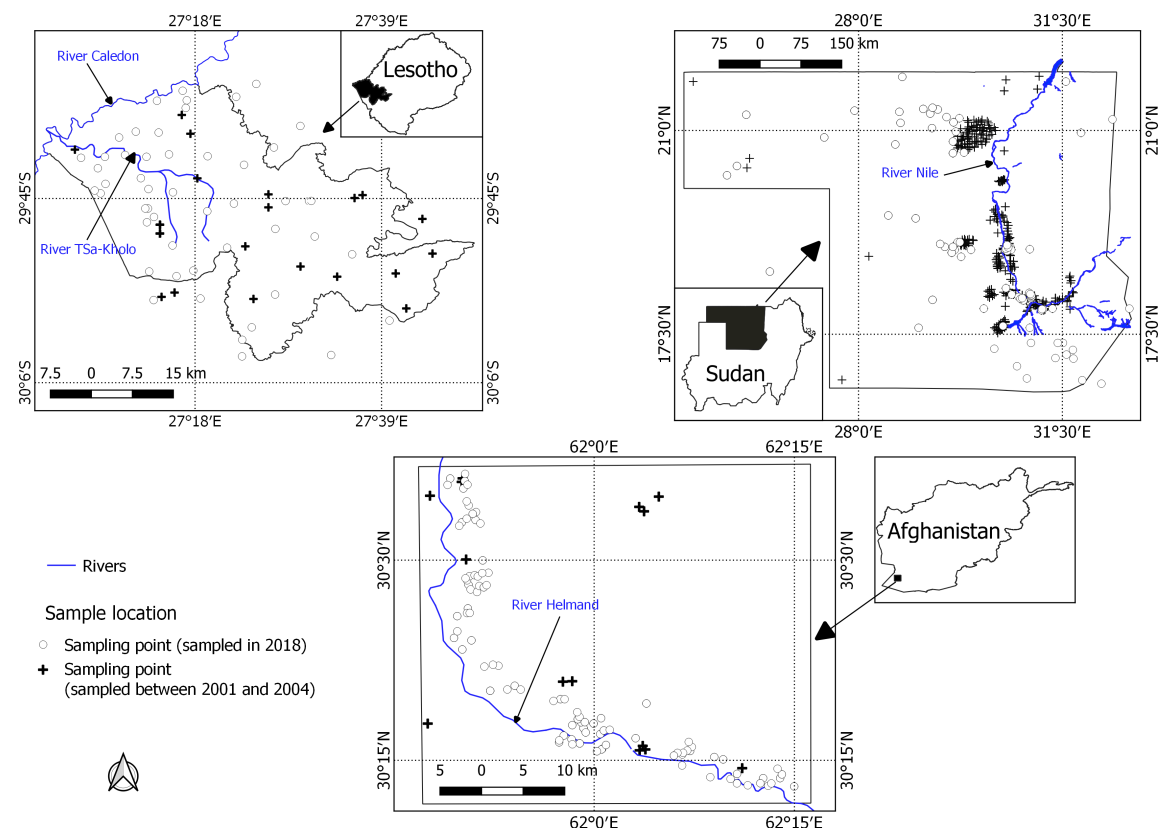


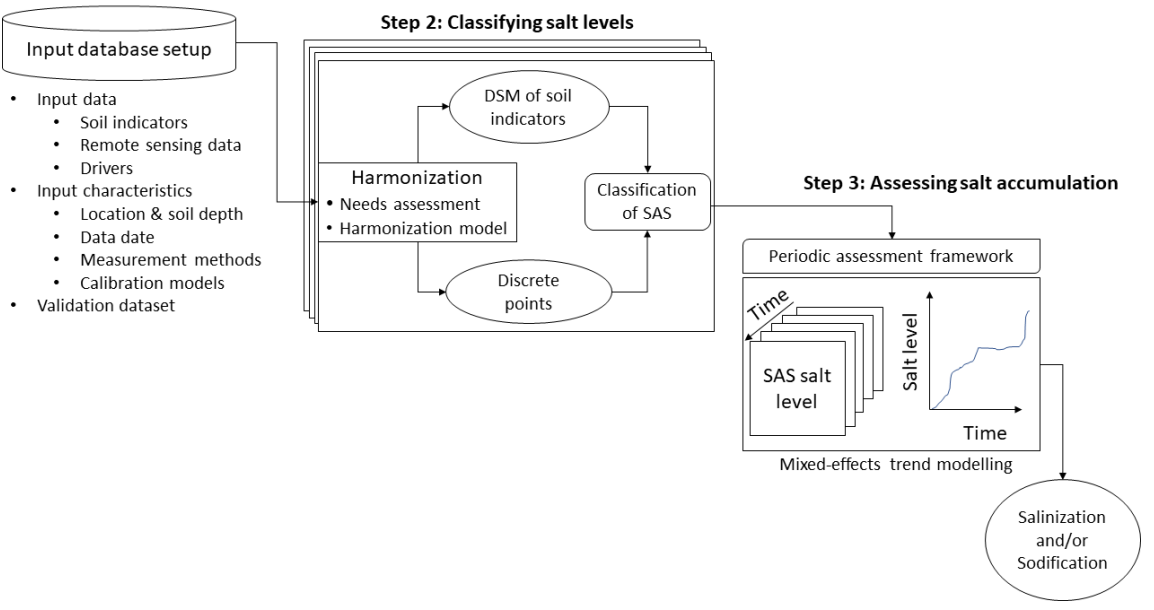

$27^{\circ} 12^{\prime} \mathrm{E} \quad 27^{\circ} 36^{\prime} \mathrm{E}$
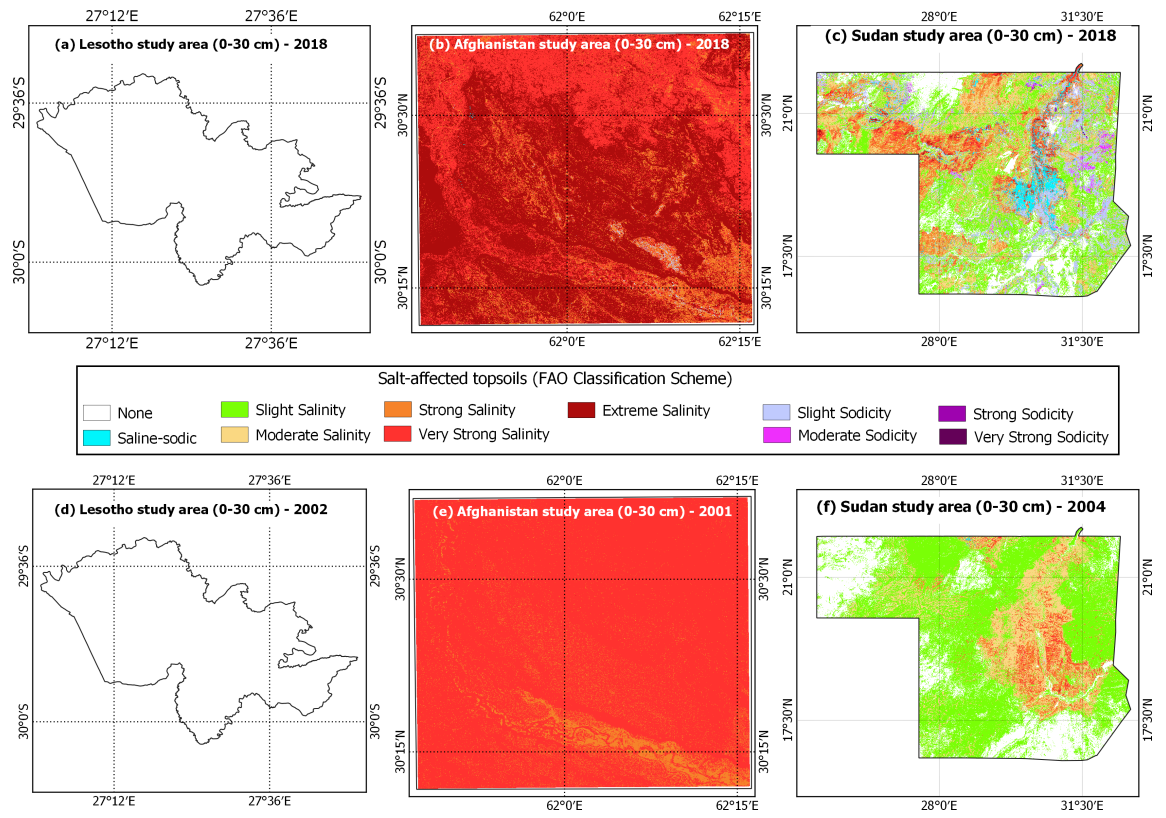

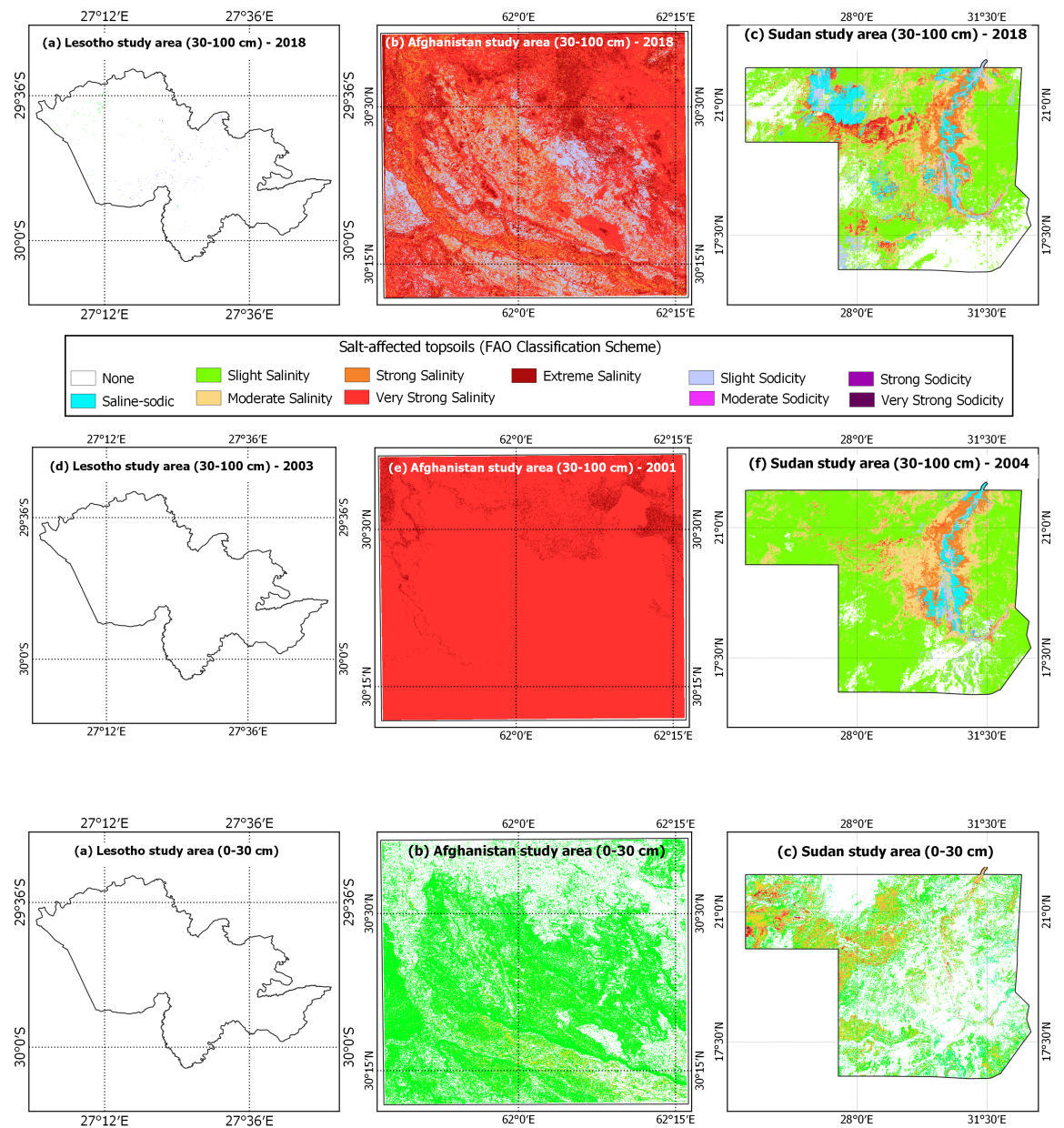

Degree of salt accumulation in the soil

$\square$ No Change or decline $\square$ Slight increase $\square$ Moderate increase $\square$ High increase $\square$ Very high increase
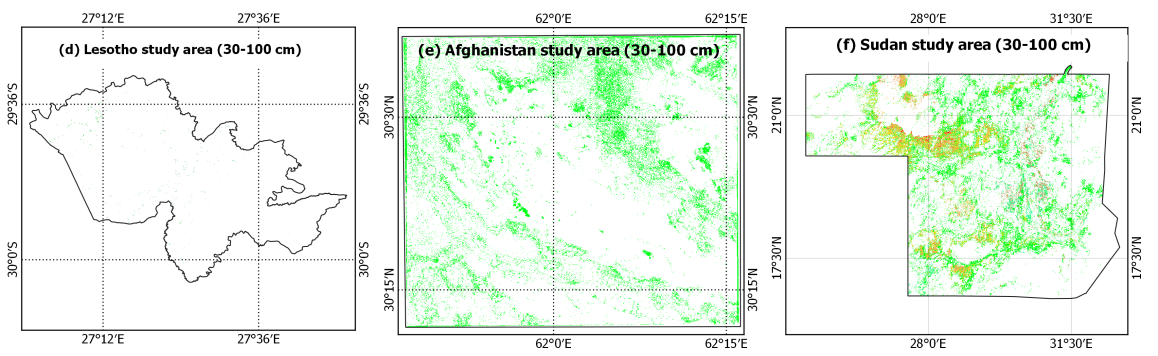